\title{
Malignant epibulbar melanoma: natural history and treatment by radiotherapy
}

\author{
M. LEDERMAN, ${ }^{*} \mathrm{~K}$. WYBAR, ${ }^{2}$ AND EILEEN BUSBY' \\ From the 'Royal Marsden Hospital and ${ }^{2}$ Moorfields Eye Hospital, London
}

\begin{abstract}
SUMmaRY One hundred and eighty-four cases of malignant melanoma of the lids and epibulbar region were seen in the Radiotherapy Department of the Royal Marsden Hospital during the period 1943-74. Some of these tumours were radiosensitive and could thus be treated by radiotherapy without loss of the affected eye. Their clinical and histological features are described. The treatment policy adopted was based on radiotherapy first, and surgery reserved for the failures. A policy of observation is advised for precancerous melanosis, and active treatment should be undertaken only if malignancy supervenes. The contraindications for radiotherapy, the factors governing radiosensitivity, and the incidence and site of metastases are reported, and the possible effect on the metastatic and survival rates of leaving the eye are discussed. Active treatment of the node-free neck is not advised. Results are given according to site, histology, and treatment method, and the frequency with which the eye was lost is shown, since the sole advantage of radiotherapy over surgery is the possibility of saving the eye without worsening the prognosis for survival.
\end{abstract}

Histological studies largely undertaken in the past decade have greatly increased our knowledge of the cutaneous malignant melanoma. This tumour, which hitherto appeared to be both incomprehensible histogenetically and unpredictable in behaviour, has as a result become more understandable, though much still remains to be discovered. Unfortunately the conclusions drawn by dermatopathologists are not generally accepted by ophthalmic pathologists, and the pathology and treatment of conjunctival malignant melanoma still present unresolved problems, which have been admirably surveyed by Jacobiec.' Despite advances made in the knowledge of the natural history of malignant melanoma there is still no general agreement on a treatment policy. Surgery understandably dominates treatment, but this dominance is largely based on fear and the laudable desire to rid the patient promptly of a tumour of evil repute. Meanwhile the therapeutic value of radiotherapy remains disputed, the malignant melanoma being customarily regarded as a radioresistant tumour and radiotherapy therefore held to be useless, if not harmful.

${ }^{*}$ Deceased

Correspondence to Dr E. Busby, Royal Marsden Hospital (Surrey Branch), Downs Road, Sutton, Surrey SM2 5PT.
It must be conceded that the history of radiotherapy in ophthalmology is an unhappy one. The early attempts to use radiant energy in the treatment of eye diseases were so calamitous that its use in the neighbourhood of the eye is regarded with trepidation to this day. However, with modern equipment and an adequate knowledge of the effects and risks of irradiating the eye it is possible to irradiate malignant tumours of the lids and epibulbar region without gross damage and still leave a useful functioning eye. The reluctance of ophthalmologists to use radiotherapy as an alternative to surgery in the treatment of epibulbar malignant melanoma is amply borne out by the infrequency with which this method receives, other than cursory or unfavourable, mention in ophthalmic literature. In this connection it is worth noting that in the third and last edition of Reese's classical work Tumours of the eye $e^{2}$ the treatment of conjunctival malignant melanoma by radiotherapy is not mentioned either in the chapter on pigmented tumours or in the one on radiotherapy.

The purpose of this paper is to try to assess the value and place of radiotherapy in the treatment of these tumours, whose rarity is generally recognised. Reese $^{3}$ stated that he had seen a total of 145 cases in 30 years. Bernadino, Naidoff, and Clark ${ }^{4}$ could obtain only 23 cases for review from over 20 ophthalmolo- 
Table 1 Epibulbar malignant melanoma 1943-74: material seen (including precancerous melanosis)

\begin{tabular}{|c|c|c|c|c|c|c|c|c|c|c|c|}
\hline \multirow[t]{2}{*}{ Histology } & & \multicolumn{4}{|l|}{ Site } & \multirow{2}{*}{$\begin{array}{l}\text { Average } \\
\text { age } \\
\text { (years) }\end{array}$} & \multicolumn{2}{|c|}{ Sex } & \multicolumn{2}{|c|}{ Side } & \multirow{2}{*}{$\begin{array}{l}\text { Average } \\
\text { duration } \\
\text { (years) }\end{array}$} \\
\hline & & Limbus & Conjunctiva & Lids & Total & & $M$ & $F$ & $R$ & $L$ & \\
\hline \multirow{2}{*}{$\begin{array}{l}\text { Malignant } \\
\text { melanoma }\end{array}$} & $\begin{array}{l}\text { Nacvus } \\
\text { origin }\end{array}$ & 21 & 9 & 4 & 34 & $\begin{array}{l}46 \cdot 5 \\
20-70\end{array}$ & 14 & 20 & 12 & 22 & $\begin{array}{l}28 \cdot 1 \\
2-69\end{array}$ \\
\hline & Nodular & 18 & 19 & 5 & 42 & $\begin{array}{l}57 \cdot 6 \\
21-83\end{array}$ & 18 & 24 & 20 & 22 & $\begin{array}{l}2 \cdot 3 \\
1 / 52-17\end{array}$ \\
\hline \multicolumn{2}{|c|}{ Cancerous melanosis } & 17 & 37 & 8 & 62 & $\begin{array}{l}54 \cdot 2 \\
25-83\end{array}$ & 20 & 42 & 27 & 35 & $\begin{array}{l}11 \cdot 7 \\
2 / 52-41\end{array}$ \\
\hline \multicolumn{2}{|c|}{ Precancerous melanosis (becoming cancerous) } & 5 & 9 & 1 & 15 & $\begin{array}{l}52 \cdot 6 \\
36-71\end{array}$ & 7 & 8 & 11 & 4 & $\begin{array}{l}12 \cdot 2 \\
2 / 12-44\end{array}$ \\
\hline \multicolumn{2}{|c|}{ Precancerous melanosis } & 10 & 17 & 4 & 31 & $\begin{array}{l}51 \cdot 5 \\
24-82\end{array}$ & 16 & 15 & 18 & 13 & $\begin{array}{l}10 \cdot 5 \\
3 / 52-41\end{array}$ \\
\hline \multicolumn{2}{|l|}{ Total } & 71 & 91 & 22 & 184 & $\begin{array}{l}53 \cdot 1 \\
20-83\end{array}$ & 75 & 109 & 88 & 96 & $\begin{array}{l}12 \cdot 7 \\
1 / 52-69\end{array}$ \\
\hline
\end{tabular}

gists. Jay ${ }^{5}$ collected a large histological series from the Institute of Ophthalmology, London, recording 104 cases seen over a period of 13 years.

Some 30 years ago one of the writers first reported the results of radiation treatment in a series of 21 cases of epibulbar malignant melanoma. ${ }^{6}$ The experience gained in this method of treatment on this admittedly small number of cases was encouraging, and the continued use of radiotherapy as an alternative to surgery was supported by results reported in 1964 on a larger series comprising 98 cases. $^{7}$ In all, during the period 1943-74 a total of 184 cases were seen in the radiotherapy department of the Royal Marsden Hospital. This clinical material is unique not only in numbers but also because radiotherapy was the main method of treatment employed.

The following account contains observations on the clinical material with special reference to the natural history of these tumours, the indications for, and the results and complications of, radiation treatment.

The term epibulbar as used here includes: (1) the palpebral and bulbar conjunctivae, the fornices, and the plica semilunaris; (2) the cornea and the limbus; (3) the cutaneous surface of the lids, the caruncle, and the intermarginal strip.

Table 1 lists some of the main features of the clinical material seen. The subdivision of the material into three main sites is in accordance with the differences in their natural history and is also of importance in the selection of radiotherapy technique.

In addition to cancerous melanosis precancerous melanosis in both its premalignant and malignant forms has been included and listed separately so as to facilitate subsequent discussion.

The higher incidence of melanoma of the limbus and conjunctiva among women and the relatively long duration of symptoms is well shown. The probable reason for the small number of lid melanomata was that they were dealt with surgically and were not referred for radiotherapy, since $\subseteq$ presumably the operations employed did not entail $\rightarrow$ loss of the eye.

The histological classification used in previous reports ${ }^{78}$ has been retained in spite of the changes in nomenclature in the past decade. The terms precancerous and cancerous melanosis employed by Reese $^{3}$ have been retained, and no doubt included among these cases are the lentigo malignant melanoma and the superficial cicatrising melanoma. The satisfactory identification of these latter tumours is even now not always practicable where the conjunctiva is concerned, ', so no attempt has been made to try to identify these two tumour varieties retrospectively.

As this material is essentially a selected one, the basis of selection being the need for radiotherapy, it cannot be used for the reliable assessment of the frequency with which the differing histological types of malignant conjunctival melanoma occur. However, Table 1 does suggest that malignant melanoma arising in a naevus is not uncommon, particularly when affecting the limbus, while precancerous and cancerous melanosis are commoner in the conjunctiva.

Though we do not enter into the controversy that still exists concerning the origin of the epibulbar malignant melanoma, it should be noted that Reese ${ }^{3}$ estimates that one-quarter of conjunctival melanomas arise from a pre-existing naevus, one-quarter de novo, and one-half from an acquired melanosis, a term suggested by Zimmerman' ${ }^{\text {to }}$ replace the terms precancerous and cancerous melanosis. Zimmerman estimated that one-half of conjunctival melanomas arise de novo, and of the remaining $50 \%$ twice as many arise from naevi as from acquired melanosis.

From Table 1 it would appear that of 153 casesthat is, apart from 31 cases of precancerous melanosis 
$-34(22 \cdot 2 \%)$ arose from pre-existing naevi, 42 $(27.4 \%)$ de novo, and $77(50.5 \%)$ from a 'previously acquired melanosis'. If the lid tumours and the precancerous melanosis cases are excluded (49 cases) and the conjunctival and limbal lesions combined (135 cases), the percentage incidence is curiously enough the same. The figures would seem to be in accordance with Reese's observations.

In view of the known difficulty in many cases of demonstrating the origin of a malignant melanoma from a pre-existing naevus, it is worth recording that in this series histological confirmation of a naeval origin was obtained in 10 of 21 limbal melanomata, 5 of 9 conjunctival melanomata, and 3 of 4 lid melanomata. In the remaining 16 cases the diagnosis of a naeval origin was made by criteria similar to those suggested by Zimmerman, ${ }^{9}$ namely: (1) a history of an unchanging lesion present since childhood or early adult life; (2) a history of a previous excision of a mole at the tumour site; (3) the absence of clinical and histological evidence of any acquired melanosis.

\section{Radiosensitivity of the malignant epibulbar melanoma}

It is obvious that treatment by radiation should be restricted to those tumours which experience shows to be radiosensitive. The phenomenon of radiosensitivity is exhibited by both normal and neoplastic tissues and relates to an inherent property of the component cells of the tissues concerned. While the radiobiological bases of radiosensitivity are complex and incompletely understood, some of the clinicopathological features that influence radiosensitivity are known and in the case of the malignant epibulbar melanomata are as follows. ${ }^{8}$

\section{TUMOUR SITE}

There appears to be a gradient of sensitivity varying from the limbus across the conjunctiva of the globe and fornices to the cutaneous surface of the lids. As a rule the nearer the tumour lies to the limbus the more radiosensitive it is and the better the prognosis with radiotherapy. Tumours of the cutaneous aspect of the lid are the least radiosensitive and usually resemble other skin melanomata in their response. Precancerous and cancerous melanosis, which are essentially multicentric lesions potentially affecting the whole conjunctival sac, are generally radiosensitive, but extensive involvement of the lids in the melanomatous process impairs the prognosis following radiotherapy. The diminution of radiosensitivity when the lid is affected can be explained by the change in character of the tumour bed. The bulbar conjunctiva is lax and mobile and related to a submucous layer, features favouring radiosensitivity, whereas the palpebral conjunctiva is adherent to the dense fibrous tarsal plates, which resemble to a lesser degree the fibrocartilaginous supporting structures of the epiglottis and pinna in their unfavourable influence on radiation response.

\section{MACROSCOPIC APPEARANCES}

Flat plaque-like lesions tend to respond slowly to radiation, and the more proliferative the tumour the prompter is the response. The degree of pigmentation is also of importance. A moderately pigmented patch near the limbus may disappear after radiotherapy, whereas a densely pigmented lesion affecting the fornices and lids may show only a limited response and may persist in an apparently harmless fashion for some time. A clear appreciation of the significance of pigmentation in relation both to neoplasia and to radiation treatment is essential. Pigment as such is merely an index of the metabolic activity of the melanocytes and need not necessarily form an integral part of the tumour. After radiation treatment it is by no means uncommon to see the tumorous element disappear and some pigment remain only to disappear at a much later date. The radiotherapist's aim is therefore not to try to depigment the eye but to achieve total disappearance of the tumour. Pigmentation if persistent and unaccompanied by tumour formation is not as a rule an indication for any active measures.

\section{MICROSCOPIC APPEARANCES}

The term malignant melanoma includes a variety of neoplasms differing in aetiology and natural history and prognosis, and not surprisingly a difference in radiosensitivity is encountered among the histological varieties listed in Table 1.

(a) It is difficult accurately to assess the true radiosensitivity of the malignant melanoma of naevus origin, since in this series wide surgical excision was performed as a preliminary in all the lid cases. However, the surgery employed for the limbal and conjunctival melomata was often merely a biopsy, and any satisfactory result obtained must be attributed mainly to the postoperative radiotherapy.

(b) The malignant melanomata arising de novo without an apparent relationship to a pre-existing mole or precancerous melanosis have nearly all proved highly radiosensitive but not necessarily radiocurable.

(c) Cancerous melanosis is in general a radiosensitive tumour, but there are variations in sensitivity, and careful selection of patients for radiotherapy is necessary. As a rule the flat, densely pigmented lesion showing extensive involvement of the fornices and lids is the least satisfactory type of tumour to treat by 
Table 2 Precancerous melanosis (46 cases): developing malignant change (15 cases)

\begin{tabular}{llllll}
\hline Total & \multicolumn{5}{l}{ Time interval before malignant change (years) } \\
\cline { 2 - 6 } & $<1$ & $1-2$ & $3-5$ & $5-10$ & $>10$ \\
\hline 15 & 3 & 3 & 4 & 4 & 1 \\
\hline
\end{tabular}

radiation, and in these cases radical surgery is to be preferred.

(d) Experience supports the view originally advanced by Reese ${ }^{10}$ that precancerous melanosis is often radiosensitive, but whether radiation or for that matter surgery should be employed for a precancerous condition is open to debate.

The recognition of the malignant potentialities of precancerous melanosis presents the clinician with a difficult therapeutic problem. When the pathologist labels a conjunctival tumour 'malignant melanoma' some form of active treatment must be offered to the patient as a matter of urgency. When, however, the histological diagnosis of precancerous melanosis is made, the clinician is forced into the situation of having to consider treatment for a condition which, without being malignant at the time of diagnosis, may become malignant at some unspecified time in the future, probably $5-10$ years according to Reese, ${ }^{2}$ but in a rather shorter time in our experience (Table 2).

The policy to be adopted as regards treatment in these circumstances must depend on: $(a)$ the clinical interpretation of the term 'precancerous'; $(b)$ the clinical assessment of the relative risks to the patient and the eye, (i) if surgical or radiation treatment is undertaken, (ii) if nothing is done and a policy of observation is adopted.

THE PRECANCEROUS STATE

Unfortunately the term 'precancerous' although widely used is rarely defined, and hence considerable confusion exists as to its significance. There are at least two possible definitions: (i) To the clinical pathologist a precancerous condition is a histological lesion composed of altered cells, which without showing invasive tendencies is known inevitably to become cancerous because of past experience with similar lesions. (ii) To the experimental pathologist a precancerous state is a histological lesion composed of altered cells which are known on a statistical basis to become cancerous with significant frequency.

It is in clinical work when the term 'precancerous' demands therapeutic action that the strictest definition is necessary, and in the absence of positive guidance from the pathologist as to the certainty of malignant change the final decision on whether or not a given precancerous condition should be treated will depend on the assessment of the clinical behaviour of the tumour. The length of history, signs of recent inflammation, or increase in extent and depth of pigmentation, and above all the appearance of tumorous nodules all assist in assessing 'activity'.

\section{RISKS OF TREATMENT}

Surgery. Theoretically any precancerous condition whether active or quiescent should be eradicated on the assumption that the formation of a cancerous growth will thereby be prevented. Because precancerous melanosis is generally a diffuse, multicentric lesion tending to involve the whole conjunctival sac, its radical surgical treatment entails either conjunctivectomy or exenteration while cryosurgery has its indications. Because of the slow growth and uncertainty as to the onset of malignancy local excision of pigmented areas has its advocates, particularly for the elderly patient. ${ }^{2}$

Radiotherapy. In spite of the apparent sensitivity of precancerous melanosis the routine use of radiotherapy in the treatment of this or any other precan-

Table 3 Precancerous melanosis: total seen (46 cases)

\begin{tabular}{|c|c|c|c|c|c|}
\hline & Total & Aliv & & Dec & \\
\hline Cases which developed malignant change & 15 & 12 & $\begin{array}{l}3>15 \text { years } \\
6>10 \text { years } \\
3>5 \text { years }\end{array}$ & 3 & $\begin{array}{l}1>15 \text { years (intercurrent) } \\
2>5 \text { years }\left(1 \text { of } 2^{\circ} \text { disease } 1 \text { intercurrent }\right.\end{array}$ \\
\hline Treated by beta rays in precancerous phase & 4 & 2 & $\begin{array}{l}1>15 \text { years } \\
1>10 \text { years }\end{array}$ & 2 & $>5$ years (intercurrent) \\
\hline Treated by surgery in precancerous phase & 5 & $4^{*}$ & $\begin{array}{l}1>20 \text { years } \\
2>10 \text { years } \\
1>3 \text { years }\end{array}$ & $1 \dagger$ & $>5$ years (cause unknown) \\
\hline Observation only (Biopsy in 7 cases) & 22 & 19 & $\begin{array}{l}2>15 \text { years } \\
6>10 \text { years } \\
6>5 \text { years } \\
5<3 \text { years }\end{array}$ & 3 & $\begin{array}{l}1>15 \text { years (intercurrent) } \\
2>5 \text { years (intercurrent) }\end{array}$ \\
\hline
\end{tabular}

*Local excision.

†Enucleation. 
cerous condition is not to be recommended on the following grounds.

(i) Full dosage has to be employed and the reactions and risks of complications are therefore the same as when treating malignant disease. Whereas the risk of ocular complications would unhesitatingly be accepted when treating an obviously malignant conjunctival tumour for which the alternative is removal of the eye, to take such risks in the case of a precancerous lesion, often of long standing, where malignancy is a supposition is rarely justified.

(ii) Radiotherapy may successfully destroy a precancerous lesion, but there is no security against recurrence and subsequent malignant change. Should such an event take place the patient is worse off than if the treatment had not been given, as in these circumstances further radiation is usually inadvisable, and the patient is thus deprived of the advantage of radiotherapy at a time when it is most needed. The use of radiotherapy as a prophylactic measure is therefore not to be recommended.

\section{OBSERVATION}

What little is known about the natural history of this precancerous condition suggests that it is a slow, rather benign process, and spontaneous resolution is not unknown. The fact that the tumour is pigmented and the term 'precancer' is used should not panic the clinician into adopting active measures other than the excision biopsy necessary when the diagnosis is in doubt. In the belief that it is the clinical behaviour of a particular tumour and not the histological label that should decide treatment, it is our opinion that an observation policy is justified and radiotherapy advised for the treatment of precancerous melanosis only in the following circumstances: (1) if the pathologist is prepared to predict with reasonable confidence that the tumour will become malignant at an early date if left; (2) the appearance of clinical features suggesting malignancy, that is, nodularity, thickening, or inflammatory signs; (3) if the lesion is by its situation, size, or extent threatening the sight of the eye.

Cases not coming within these categories may be safely kept under regular observation and any changes assessed on clinical grounds. A biopsy should be performed if any doubt arises. Because of the relative benignity of the lesion routine biopsy is not essential to establish the diagnosis, nor is repeated biopsy necessary to determine progress. In this connection Zimmerman ${ }^{9}$ also expressed the opinion that in the absence of nodularity or thickening biopsy is not essential.

Table 3 illustrates the results of this policy of

Table 4a Malignant melanoma (nodular and naevoid): complications of treatment

\begin{tabular}{lcccc}
\hline Site & Patients treated & $\begin{array}{l}\text { Patients with } \\
\text { complications }\end{array}$ & Cataract & Glaucoma \\
\hline Limbus & 37 & 11 & 4 & 5 \\
Conjunctiva & 26 & 7 & 2 & 4 \\
Lids & 9 & 1 & 0 & 1 \\
Total & 72 & 19 & 6 & 10 \\
\hline
\end{tabular}

Table $4 \mathrm{~b}$ Cancerous melanosis: complications of treatment

\begin{tabular}{lccccc}
\hline Site & Patients treated & $\begin{array}{l}\text { Patients with } \\
\text { complications }\end{array}$ & Cataract & Corneal.damage & Glaucoma \\
\hline Limbus & 15 & 8 & 6 & 2 & 2 \\
Conjunctiva & 36 & 17 & 0 & 11 & 7 \\
Lids & 8 & 0 & 14 & 0 & 0 \\
Total & 59 & 25 & & 13 & 9 \\
\hline
\end{tabular}

Table 4c Precancerous melanosis which became cancerous: complications of treatment

\begin{tabular}{lllllc}
\hline Site & Patients treated & $\begin{array}{l}\text { Patients with } \\
\text { complications }\end{array}$ & Cataract & Corneal damage & Glaucoma \\
\hline Limbus & & 1 & 0 & 1 & 0 \\
Conjunctiva & 5 & 3 & 2 & 1 & 0 \\
Lids & 9 & 0 & 0 & 0 & 0 \\
Total & 1 & 4 & 2 & 2 & 0 \\
\hline
\end{tabular}


observation and the results of treatment where this has been judged necessary. Of 46 cases seen 15 (32.6\%) underwent malignant change as compared with $17 \%$ in Reese's series. ${ }^{3}$ Nine patients were treated for precancerous melanosis, four by radiotherapy because they came into one of the categories listed above, and five by surgery, all of whom were so treated prior to referral. Twentytwo patients (in seven of whom the lesion was confirmed by biopsy) were not treated and have remained under observation from 1 to 17 years.

The tables show that of the 37 patients originally kept under observation none has suffered because of this policy. Even among the 15 cases where malignant transformation occurred there was only one death from metastatic disease, where the primary site was the lid (Table 9).

\section{Technique of radiation treatment of the epibulbar melanomata}

Local excision of any exuberant tumour mass is an essential preliminary to radiation treatment. By this means biopsy material is obtained and a reasonably flat surface provided for the local application of radioactive sources. Where there is little elevation of the tumour, a biopsy alone should be undertaken and the tumour otherwise left undisturbed.

Three technical methods of treatment were available during the period covered by this report using beta radiation, gamma radiation, and $x$-radiation.

The precise techniques have been described in detail elsewhere. ${ }^{8}$

\section{Complications}

The following complications were encountered in this series of cases (Tables $4 a, b, c)$.

(1) Cataract. This complication is to be expected in all cases treated by $\gamma$ or $x$-radiation and to a lesser extent by $\beta$ radiation and has developed in $16 / 72$ $(21.6 \%)$ of the cancerous melanosis group and in $6 / 72$ $(8.4 \%)$ in the malignant melanoma group where $\beta$ rays were frequently employed. The time interval between treatment and the onset of the cataract has varied between two and 11 years, the majority occurring between three and five years. Radiation cataracts are amenable to surgical removal and this has been undertaken in six cases.

(2) Epilation of the lashes and occasionally the eyebrows occurs and is rarely a cause of complaint. The lashes often regrow white whatever the colouring of the patient.

(3) The lids undergo a certain amount of atrophy and fibrosis which may result in narrowing of the palpebral fissure. Where tumours involving the fornices have been first excised and then treated by radiation, there is a tendency to symblepharon.

Irradiation of the palpebral conjunctivae whether 으 by $\beta$ or $x$ radiation may give rise to keratinisation of $\vec{\Rightarrow}$ the mucous surface, and the eye may as a con- $\stackrel{\oplus}{+}$ sequence become red and irritable. Occasionally a rough keratinised patch on the palpebral surface of $\overline{\bar{D}}$ the lid may produce corneal damage. This complica- $\frac{\mathscr{T}}{\sigma}$ tion tends to occur after heavy localised $x$ radiation $\unrhd$ such as is used in the treatment of lid cancers, but it usually responds satisfactorily to the prolonged use of $\overrightarrow{0}$ topical steroids with the development only rarely of permanent changes. These occur when the corneal $\vec{\omega}$ damage is sufficiently extensive to produce a bullous $\frac{\sigma}{\partial}$ keratopathy. Keratinisation has occurred to a troublesome extent in one case in this series-a precancerous melanosis treated by $\beta$ radiation applied to both 6 bulbar and palpebral conjunctivae.

(4) Glaucoma following radiotherapy may occur of after $\beta$ as well as $\gamma$ and $x$ radiation. Nine of the 74 을 cases of cancerous melanosis developed glaucoma, $\vec{c}$ and the same number occurred in the 72 cases of $\mathbb{D}$ malignant melanoma where many of the patients had $\frac{\vec{D}}{\vec{D}}$ $\beta$ radiation.

(5) There were 25 cases of corneal damage of varying degree: 15 out of $74(20 \cdot 2 \%)$ of the patients treated for cancerous melanosis and 10 out of $72(12.4 \%)$ of $ळ$ those treated for malignant melanoma.

(6) Of 146 cases ( 74 cancerous melanosis and 72 뭉 malignant melanoma) 9 patients had the eye removed either before referral or as an alternative to radio- $\bar{\partial}$ therapy. Of the remaining 137 patients (69 cancerous melanosis and 68 malignant melanoma) all treated by $\stackrel{\mathbb{2}}{\varrho}$ radiotherapy 36 patients (approximately 25\%) lost $\overrightarrow{\overrightarrow{0}}$ the eye, but of these in only 12 cases $(9 \%)$ could this 3 loss be attributed to radiation damage alone.

The added risk of using $\gamma$ radiation is shown by the fact that the eye was removed for radiation damage in $\frac{\partial}{0}$. eight of 69 patients $(11.6 \%)$ with cancerous melanosis where the whole conjunctival sac was treated by $\gamma \frac{0}{3}$ radiation as opposed to four of 68 of the malignant melanoma patients $(5 \cdot 8 \%)$ where $\beta$ or $x$ radiation was $\frac{0}{3}$ applied to localised areas of the conjunctival sac.

METASTASES

In those situations where radiotherapy is to be 'considered as an alternative to limited or ablative surgery $N$ the argument is frequently and understandably $N$ advanced that the risks of regional metastases or $\mathrm{N}$ general dissemination might be increased by leaving $\omega_{\sigma}$ the tumour undisturbed for radiation treatment. In all tumour sites where radiotherapy has established $\stackrel{\circ}{\simeq}$ itself as an acceptable alternative to surgery it has yet $\stackrel{\mathscr{D}}{\circ}$ to be shown that patients receiving this treatment are at a greater metastatic risk than those undergoing $\frac{T}{0}$ surgery. It would appear that excisional surgery gives $\overrightarrow{\mathbb{D}}$ 
Table 5a Malignant melanoma (nodular and naevoid), cervical nodes, and distant metastases

\begin{tabular}{|c|c|c|c|c|c|c|c|c|c|c|c|c|}
\hline \multirow[t]{2}{*}{ Site } & \multirow{2}{*}{$\begin{array}{l}\text { Patients } \\
\text { treated }\end{array}$} & \multirow{2}{*}{$\begin{array}{l}\text { Patients } \\
\text { with } \\
\text { cervical } \\
\text { nodes }\end{array}$} & \multirow{2}{*}{$\begin{array}{l}\text { Patients } \\
\text { with } \\
\text { distant } \\
\text { metastases }\end{array}$} & \multicolumn{9}{|c|}{ Sites of distant metastases } \\
\hline & & & & Chest & Liver & $\begin{array}{l}\text { Skin and } \\
\text { subcutaneous }\end{array}$ & Abdominal & Bones & Brain & $\begin{array}{l}\text { Other } \\
\text { nodes }\end{array}$ & $\begin{array}{l}\text { Spinal } \\
\text { cord }\end{array}$ & $\begin{array}{l}\text { Not } \\
\text { known }\end{array}$ \\
\hline Limbus & 37 & 4 & 6 & 2 & 0 & 3 & 2 & 1 & 2 & 0 & 0 & 1 \\
\hline Conjunctiva & 26 & 6 & 10 & 3 & 4 & 3 & 3 & 1 & 1 & 1 & 0 & 2 \\
\hline Lids & 9 & 1 & 2 & 0 & 0 & 1 & 0 & 2 & 0 & 1 & 1 & 0 \\
\hline Total & 72 & 11 & $19^{*}$ & 5 & 4 & 7 & 5 & 4 & 3 & 2 & 1 & 4 \\
\hline
\end{tabular}

${ }^{*}$ Necropsy performed in 2 cases.

Table 5b Cancerous melanosis, cervical nodes, and distant metastases

\begin{tabular}{|c|c|c|c|c|c|c|c|c|c|c|c|c|c|c|}
\hline \multirow[t]{2}{*}{ Site } & \multirow{2}{*}{$\begin{array}{l}\text { Patients } \\
\text { treated }\end{array}$} & \multirow{2}{*}{$\begin{array}{l}\text { Patients } \\
\text { with } \\
\text { cervical } \\
\text { nodes }\end{array}$} & \multirow{2}{*}{$\begin{array}{l}\text { Patients } \\
\text { with } \\
\text { distant } \\
\text { met- } \\
\text { astases }\end{array}$} & \multicolumn{11}{|c|}{ Sites of distant metastases } \\
\hline & & & & Chest & Liver & $\begin{array}{l}\text { Skin and } \\
\text { subcutaneous }\end{array}$ & Abdominal & Bones & Brain & $\begin{array}{l}\text { Other } \\
\text { nodes }\end{array}$ & Breast & Thyroid & Testicle & $\begin{array}{l}\text { Not } \\
\text { known }\end{array}$ \\
\hline Limbus & 15 & 2 & 2 & 0 & 1 & 1 & 1 & 1 & 0 & 1 & 0 & 0 & 0 & 0 \\
\hline Conjunctiva & 36 & 5 & 13 & 6 & 7 & 4 & 4 & 4 & 4 & 3 & 1 & 2 & 0 & 2 \\
\hline Lids & 8 & 0 & 3 & 3 & 1 & 0 & 2 & 0 & 1 & 1 & 0 & 0 & 1 & 0 \\
\hline Total & 59 & 7 & $19^{*}$ & 9 & 9 & 5 & 7 & 5 & 5 & 5 & 1 & 2 & 1 & 2 \\
\hline
\end{tabular}

Necropsy performed in 6 cases.

Table 5c Precancerous melanosis which became cancerous, cervical nodes, and distant metastases

\begin{tabular}{|c|c|c|c|c|c|}
\hline \multirow[t]{2}{*}{ Site } & \multirow[t]{2}{*}{$\begin{array}{l}\text { Patients } \\
\text { treated }\end{array}$} & \multirow{2}{*}{$\begin{array}{l}\text { Patients } \\
\text { with } \\
\text { cervical } \\
\text { nodes }\end{array}$} & \multirow{2}{*}{$\begin{array}{l}\text { Patients } \\
\text { with } \\
\text { distant } \\
\text { metastases }\end{array}$} & \multicolumn{2}{|c|}{$\begin{array}{l}\text { Sites of } \\
\text { distant } \\
\text { metastases }\end{array}$} \\
\hline & & & & Liver & Skin \\
\hline Limbus & 5 & 0 & 0 & 0 & 0 \\
\hline Conjunctiva & 9 & 0 & 0 & 0 & 0 \\
\hline Lids & 1 & 0 & 1 & 1 & 1 \\
\hline Total & 15 & 0 & 1 & 1 & 1 \\
\hline
\end{tabular}

no greater immunity against local recurrence or metastases than does radiotherapy, since in both instances the behaviour of a given tumour depends on its inherent biological characteristics rather than the particular treatment administered.

There is little information in the literature concerning the incidence of regional and distant metastases relative to the epibulbar malignant melanomata. Reese $^{3}$ mentioned that there was a $40 \%$ mortality among his cancerous melanosis patients but did not specify the cause of death. Reese also advised elective radical neck dissection as part of the initial surgical treatment of cancerous melanosis, though the rationale and value of this procedure seem uncertain.

Ophthalmic pathologists have not been able to add greatly to our knowledge of the metastatic aspect of the natural history of these tumours. While tribute must be paid to the value of their contributions to the histological interpretation and classification of malignant melanomata, they are handicapped by lack of opportunity for clinical follow-up of the patients or necropsy investigation in the event of the patient's death.

It appears therefore of some interest to record in this series of cases: (1) the incidence and site of the metastases observed; (2) whether removal of the eye influences this incidence.

The incidence of metastases. Tables $5 \mathrm{a}, \mathrm{b}$, and $\mathrm{c}$ show the incidence of cervical lymph node metastases, and distant metastases, and the distribution of the latter. The figures in these tables do not represent individual patients, since one patient might show metastases at more than one site.

It can be seen that cervical lymph node metastases developed during the course of the disease in seven out of $59(11.8 \%)$ of the cancerous melanosis cases: None of the 15 cases of malignant change in a precancerous melanosis developed nodes, while in the malignant melanomata 11 out of $72(15.3 \%)$ developed nodes.

The sites at which the 18 cases developed nodes was as follows: limbus, 6 cases; conjunctiva, 11 cases; lids, 1 case. With an overall metastatic node incidence of 18 out of 146 , that is, $12 \cdot 7 \%$, neither elective dissection nor irradiation of the clinically node-free neck would appear to be justified.

If one can speculate on these figures, it would seem that cervical lymph node metastases as the only metastatic manifestation is uncommon, and when a 
patient does develop such metastatic nodes there is a high chance that more distant metastases may exist concomitantly.

In all the histological types where dissemination occurred the metastases were wide ranging in site with the chest, skin and intra-abdominal organs, and specially the liver affected.

The conjunctiva appears to be the primary site most frequently associated with metastases, but the limbus is noteworthy in the case of the malignant melanoma group.

\section{REMOVAL OF THE EYE}

Removal of the eye does not seem to influence materially the incidence of regional or distant metastases, as Tables $6 \mathrm{a}, \mathrm{b}$, and $\mathrm{c}$ show. Of 74 cases of cancerous melanosis (including the 15 cases developing from precancerous lesions) 47 retained the eye, and in 27 patients the eye was removed (including 12 cases of radiation damage) and nine prior to referral as a surgical alternative to radiotherapy. In the group retaining the eye metastases occurred in 12 out of 47 cases $(26 \%)$, while in the group losing the eye metastases occurred in seven out of 27 cases $(26 \%)$, so that there was no difference in the two groups.

Of the 55 of the 72 cases of malignant melanoma where the eye was left, 11 developed metastatic disease $(20 \%)$. Of the 19 cases where the eye was removed 11 developed metastases $(57 \%)$. It is difficult to know the precise significance of these figures, but they do seem to support the view that leaving the affected eye for radiation treatment does not appear to add to the metastatic risk.

Table 6a Malignant melanoma (nodular and naevoid), cervical nodes, and distant metastases in relation to removal of eye

\begin{tabular}{|c|c|c|c|c|c|c|c|c|c|}
\hline \multirow[t]{2}{*}{ Site } & \multirow{2}{*}{$\begin{array}{l}\text { Patients } \\
\text { treated }\end{array}$} & \multicolumn{4}{|c|}{ Eye present (53 cases) } & \multicolumn{4}{|c|}{ Eye removed (19 cases) } \\
\hline & & $\begin{array}{l}\text { No } \\
\text { spread }\end{array}$ & $\begin{array}{l}\text { Cervical } \\
\text { nodes only }\end{array}$ & $\begin{array}{l}\text { Distant } \\
\text { metastases } \\
\text { only }\end{array}$ & $\begin{array}{l}\text { Cervical } \\
\text { nodes and } \\
\text { distant } \\
\text { metastases }\end{array}$ & $\begin{array}{l}\text { No } \\
\text { spread }\end{array}$ & $\begin{array}{l}\text { Cervical } \\
\text { nodes only }\end{array}$ & $\begin{array}{l}\text { Distant } \\
\text { metastases } \\
\text { only }\end{array}$ & $\begin{array}{l}\text { Cervical } \\
\text { nodes and } \\
\text { distant } \\
\text { metastases }\end{array}$ \\
\hline Limbus & 37 & 25 & 0 & 0 & 1 & 5 & 1 & 3 & 2 \\
\hline Conjunctiva & 26 & 10 & 2 & 5 & 2 & 3 & 1 & 2 & 1 \\
\hline Lids & 9 & 7 & 0 & 0 & 1 & 0 & 0 & 1 & 0 \\
\hline Total & 72 & 42 & 2 & 5 & 4 & 8 & 2 & 6 & 3 \\
\hline
\end{tabular}

Table $6 \mathrm{~b}$ Cancerous melanosis, cervical nodes, and distant metastases in relation to removal of eye

\begin{tabular}{|c|c|c|c|c|c|c|c|c|c|}
\hline \multirow[t]{2}{*}{ Site } & \multirow{2}{*}{$\begin{array}{l}\text { Patients } \\
\text { treated }\end{array}$} & \multicolumn{4}{|c|}{ Eye present (35 cases) } & \multicolumn{4}{|c|}{ Eye removed (24 cases) } \\
\hline & & $\begin{array}{l}\text { No } \\
\text { spread }\end{array}$ & $\begin{array}{l}\text { Cervical } \\
\text { nodes only }\end{array}$ & $\begin{array}{l}\text { Distant } \\
\text { metastases } \\
\text { only }\end{array}$ & $\begin{array}{l}\text { Cervical } \\
\text { nodes and } \\
\text { distant } \\
\text { metastases }\end{array}$ & $\begin{array}{l}\text { No } \\
\text { spread }\end{array}$ & $\begin{array}{l}\text { Cervical } \\
\text { nodes only }\end{array}$ & $\begin{array}{l}\text { Distant } \\
\text { metastases } \\
\text { only }\end{array}$ & $\begin{array}{l}\text { Cervical } \\
\text { nodes and } \\
\text { distant } \\
\text { metastases }\end{array}$ \\
\hline Limbus & 15 & 10 & 0 & 0 & 1 & 3 & 0 & 0 & 1 \\
\hline Conjunctiva & 36 & 10 & 0 & 5 & 2 & 13 & 0 & 3 & $3^{*}$ \\
\hline Lids & 8 & 4 & 0 & 3 & 0 & 1 & 0 & 0 & 0 \\
\hline Total & 59 & 24 & 0 & 8 & 3 & 17 & 0 & 3 & 4 \\
\hline
\end{tabular}

*Two patients presented with cervical nodes. Both developed distant metastases later.

Table 6c Precancerous melanosis which became cancerous, cervical nodes, and distant metastases in relation to removal of eye

\begin{tabular}{|c|c|c|c|c|c|c|c|c|c|}
\hline \multirow[t]{2}{*}{ Site } & \multirow{2}{*}{$\begin{array}{l}\text { Patients } \\
\text { treated }\end{array}$} & \multicolumn{4}{|c|}{ Eye present ( 12 cases) } & \multicolumn{4}{|c|}{ Eye removed (3 cases) } \\
\hline & & $\begin{array}{l}\text { No } \\
\text { spread }\end{array}$ & $\begin{array}{l}\text { Cervical } \\
\text { nodes only }\end{array}$ & $\begin{array}{l}\text { Distant } \\
\text { metastases } \\
\text { only }\end{array}$ & $\begin{array}{l}\text { Cervical } \\
\text { nodes and } \\
\text { distant } \\
\text { metastases }\end{array}$ & $\begin{array}{l}\text { No } \\
\text { spread }\end{array}$ & $\begin{array}{l}\text { Cervical } \\
\text { nodes only }\end{array}$ & $\begin{array}{l}\text { Distant } \\
\text { metastases } \\
\text { only }\end{array}$ & $\begin{array}{l}\text { Cervical } \\
\text { nodes and } \\
\text { distant } \\
\text { metastases }\end{array}$ \\
\hline Limbus & 5 & 5 & 0 & 0 & 0 & 0 & 0 & 0 & 0 \\
\hline Conjunctiva & 9 & 6 & 0 & 0 & 0 & 3 & 0 & 0 & 0 \\
\hline Lids & 1 & 0 & 0 & 1 & 0 & 0 & 0 & 0 & 0 \\
\hline Total & 15 & 11 & 0 & 1 & 0 & 3 & 0 & 0 & 0 \\
\hline
\end{tabular}


Table 7a Malignant melanoma (nodular and naevoid): results of treatment. Total treated (72), limbus (37 cases)

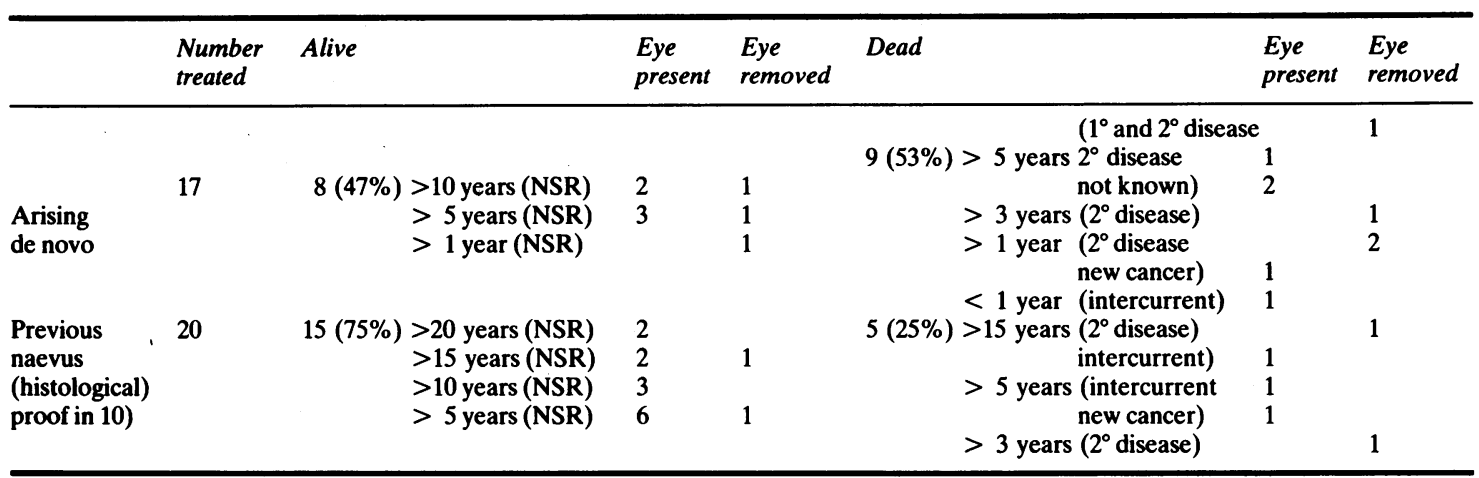

NSR=no sign of recurrence.

Table $7 \mathrm{~b}$ Malignant melanoma (nodular and naevoid): results of treatment. Total treated (72), conjunctiva (26 cases)

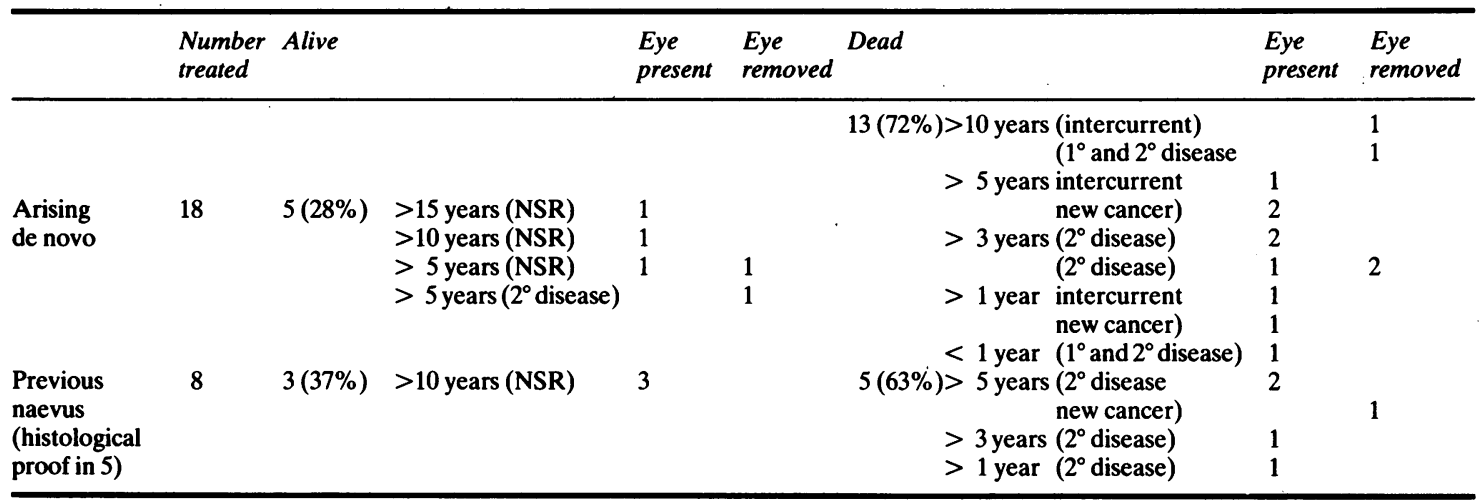

Table 7c Malignant melanoma (nodular and naevoid): results of treatment. Total treated (72), lids (9 cases)

\begin{tabular}{|c|c|c|c|c|c|c|c|c|}
\hline & $\begin{array}{l}\text { Number } \\
\text { treated }\end{array}$ & Alive & & $\begin{array}{l}\text { Eye } \\
\text { present }\end{array}$ & $\begin{array}{l}\text { Eye } \\
\text { removed }\end{array}$ & Dead & $\begin{array}{l}\text { Eye } \\
\text { present }\end{array}$ & $\begin{array}{l}\text { Eye } \\
\text { removed }\end{array}$ \\
\hline $\begin{array}{l}\text { Arising } \\
\text { de novo }\end{array}$ & 5 & $2(40 \%)$ & $\begin{array}{l}>25 \text { years }(\text { NSR }) \\
>3 \text { years }(? N S R)\end{array}$ & $\begin{array}{l}1 \\
1\end{array}$ & & $\begin{aligned} & 3(60 \%)>3 \text { years }\left(2^{\circ} \text { disease }\right. \\
&\text { not known }) \\
&<1 \text { year }\left(1^{\circ}\left(\text { and } ? 2^{\circ}\right)\right. \\
&\text { disease })\end{aligned}$ & $\begin{array}{l}1 \\
1 \\
1\end{array}$ & \\
\hline $\begin{array}{l}\text { Previous } \\
\text { naevus } \\
\text { (histological } \\
\text { proof in 3) }\end{array}$ & 4 & $2(50 \%)$ & $\begin{array}{l}>5 \text { years }(\text { NSR }) \\
>1 \text { year }(\text { NSR })\end{array}$ & $\begin{array}{l}1 \\
1 \\
-\end{array}$ & & $\begin{aligned} 2(50 \%) & >10 \text { years }(\text { new cancer }) \\
& >3 \text { years }\left(2^{\circ} \text { disease }\right)\end{aligned}$ & 1 & 1 \\
\hline
\end{tabular}

\section{Results of treatment}

In the presentation of the results of radiation treatment of epibulbar malignant melanoma certain difficulties have to be borne in mind. These are:

(1) Current teaching and practice are based on the assumption that malignant melanomata are both highly malignant and radioresistant, and that ablative surgery is the treatment of choice. At one time Reese $^{11}$ considered cancerous melanosis to be the most malignant tumour encountered in ophthalmology, but later tempered ${ }^{2}$ this view in that, while still advocating exenteration as the treatment of choice, indications for lesser procedures such as partial excision with postoperative radiotherapy were accepted. However, irrespective of the nature of the operation performed routine elective neck dissection is advised.

(2) When dealing with a rare disease about whose natural history little is known and for which no certain 
remedy exists it is very easy to become a partisan of a given method of treatment, particularly radiotherapy, which is without the mutilating consequence of surgery. In order to avoid this pitfall two essential steps have been taken: (i) The diagnosis in all malignant cases reported in this series has been confirmed histologically. (ii) Statements concerning the treatment policy are based on the results, though it must be conceded that any conclusions drawn from a retrospective historical study of this kind are beset with statistical hazards. Table 7a, b and c shows the results obtaining in the treatment of the malignant melanoma of the nodular or naeval origin.

As the main purpose of radiotherapy was to attempt to save the eye, the frequency with which the eye was in fact lost is also shown. It can be seen that the best results as far as disease control and retention of the eye is concerned are found in limbal tumours of naeval origin.

The nodular melanoma of the conjunctiva appears to have the worst prognosis. Five of 18 patients survived of whom only three retained the eye. Nodular lesions of the limbus fare somewhat better with eight out of 17 survivors, five retaining the eye. Of the nine patients with lid melanomata which were treated with a combination of surgery and radiotherapy only four survived.

Tables $8 \mathrm{a}, \mathrm{b}$ and $\mathrm{c}$ show the results of treatment of cancerous melanosis. Although this disease is regarded as affecting the whole of the conjunctival sac, the results are given according to treatment method and apparent site of origin of the tumour. Those cases where malignancy supervened in a precancerous lesion are separately listed (Table 9).

Table 8a Cancerous melanosis: results of treatment. Total treated (59), limbus (15 cases)

\begin{tabular}{|c|c|c|c|c|c|c|c|c|c|}
\hline Treatment & $\begin{array}{l}\text { Number } \\
\text { treated }\end{array}$ & Alive & & $\begin{array}{l}\text { Eye } \\
\text { present }\end{array}$ & $\begin{array}{l}\text { Eye } \\
\text { removed }\end{array}$ & Dead & & $\begin{array}{l}\text { Eye } \\
\text { present }\end{array}$ & $\begin{array}{l}\text { Eye } \\
\text { removed }\end{array}$ \\
\hline Radiotherapy & 15 & $13(87 \%)$ & $\begin{array}{l}>20 \text { years }(\text { NSR }) \\
>15 \text { years }(\text { NSR }) \\
>15 \text { years }\left(1^{\circ} \text { disease }\right) \\
>10 \text { years }(\text { NSR }) \\
>5 \text { years }\left(1^{\circ} \text { disease }\right)\end{array}$ & $\begin{array}{l}2 \\
4 \\
1 \\
2 \\
1\end{array}$ & $\begin{array}{l}2 \\
1\end{array}$ & $2(13 \%)$ & $\begin{array}{l}>10 \text { years }\left(2^{\circ} \text { disease }\right) \\
>1 \text { year }\left(2^{\circ} \text { disease }\right)\end{array}$ & 1 & 1 \\
\hline
\end{tabular}

$\mathrm{NSR}=$ no sign of recurrence.

Table 8b Cancerous melanosis: results of treatment. Total treated (59), conjunctiva (36 cases)

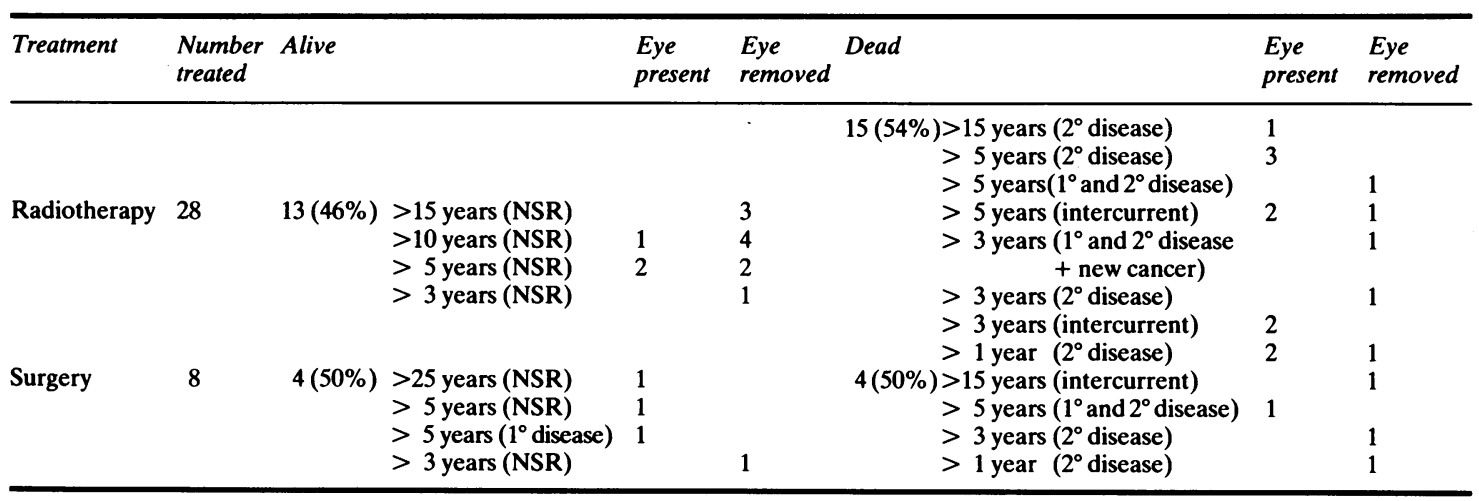

Table 8c Cancerous melanosis: results of treatment. Total treated (59), lids (8 cases)

\begin{tabular}{|c|c|c|c|c|c|c|c|c|c|}
\hline Treatment & $\begin{array}{l}\text { Number } \\
\text { treated }\end{array}$ & Alive & . & $\begin{array}{l}\text { Eye } \\
\text { present }\end{array}$ & $\begin{array}{l}\text { Eye } \\
\text { removed }\end{array}$ & Dead & & $\begin{array}{l}\text { Eye } \\
\text { present }\end{array}$ & $\begin{array}{l}\text { Eye } \\
\text { removed }\end{array}$ \\
\hline Radiotherapy & 7 & $2(29 \%)$ & $\begin{array}{l}>10 \text { years }(\text { NSR) } \\
<1 \text { year }(\text { NSR) }\end{array}$ & $\begin{array}{l}1 \\
1\end{array}$ & & $5(71 \%)$ & $\begin{array}{l}>10 \text { years (intercurrent) } \\
>1 \text { year }\left(1^{\circ} \text { and } 2^{\circ} \text { disease }\right) \\
>1 \text { year }\left(2^{\circ} \text { disease }\right) \\
>1 \text { year }(\text { new cancer }) \\
<1 \text { year }\left(1^{\circ} \text { and } 2^{\circ} \text { disease }\right)\end{array}$ & $\begin{array}{l}1 \\
1 \\
1 \\
1\end{array}$ & 1 \\
\hline Surgery & 1 & 1 & $>20$ years $($ NSR $)$ & 1 & & & & & \\
\hline
\end{tabular}


Table 9 Precancerous melanosis which became cancerous: results of treatment. Total treated (15)

\begin{tabular}{|c|c|c|c|c|c|c|c|c|c|}
\hline Treatment & $\begin{array}{l}\text { Number } \\
\text { treated }\end{array}$ & Alive & & $\begin{array}{l}\text { Eye } \\
\text { present }\end{array}$ & $\begin{array}{l}\text { Eye } \\
\text { removed }\end{array}$ & Dead & & $\begin{array}{l}\text { Eye } \\
\text { present }\end{array}$ & $\begin{array}{l}\text { Eye } \\
\text { removed }\end{array}$ \\
\hline \multicolumn{10}{|c|}{ Limbus (5 cases)! } \\
\hline Radiotherapy & 4 & $3(75 \%)$ & $\begin{array}{l}>10 \text { years }(\mathrm{NSR}) \\
>5 \text { years }(\mathrm{NSR})\end{array}$ & $\begin{array}{l}2 \\
1\end{array}$ & & $1(25 \%)$ & $>15$ years (intercurrent) & 1 & \\
\hline $\begin{array}{l}\text { Surgery } \\
\text { Conjunctiva }(9\end{array}$ & $\begin{array}{l}1 \\
\text { cases) }\end{array}$ & 1 & $>10$ years $(\mathrm{NSR})$ & 1 & & & & & \\
\hline Radiotherapy & 8 & $7(87 \%)$ & $\begin{array}{l}>15 \text { years }(\text { NSR) } \\
>10 \text { years }(\text { NSR) } \\
>5 \text { years }(\text { NSR) }\end{array}$ & $\begin{array}{l}1 \\
3 \\
1\end{array}$ & $\begin{array}{l}1 \\
1\end{array}$ & $1(13 \%)$ & $>5$ years (intercurrent) & 1 & \\
\hline $\begin{array}{l}\text { Surgery } \\
\text { Lids (1 case) }\end{array}$ & 1 & 1 & $>15$ years (NSR) & & 1 & & & & \\
\hline Surgery & 1 & & & & & 1 & $>5$ years $\left(2^{\circ}\right.$ disease $)$ & 1 & \\
\hline
\end{tabular}

NSR =no sign of recurrence.

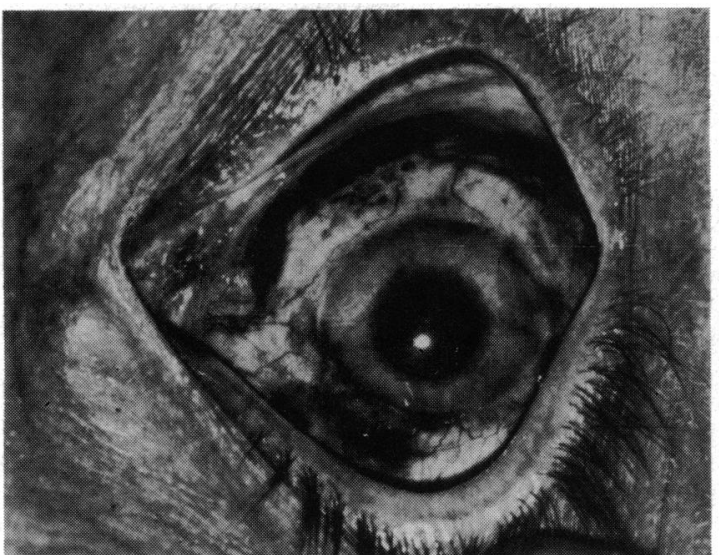

Fig. 1A Before treatment. Man of 59 years with precancerous melanosis becoming cancerous. Treated by radon seed implant. Dose 4500 rads in 94 hours.

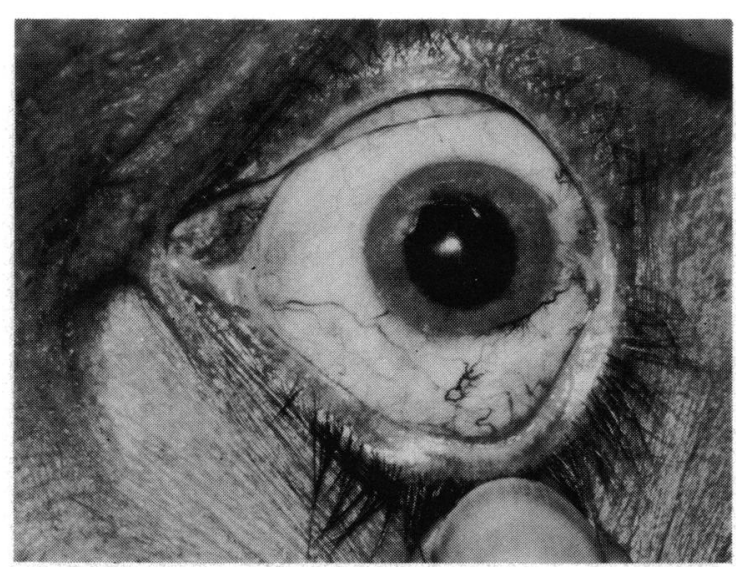

Fig. 1B Two years after treatment. The patient remained well but died of intercurrent disease nine years after treatment. There was no local recurrence.

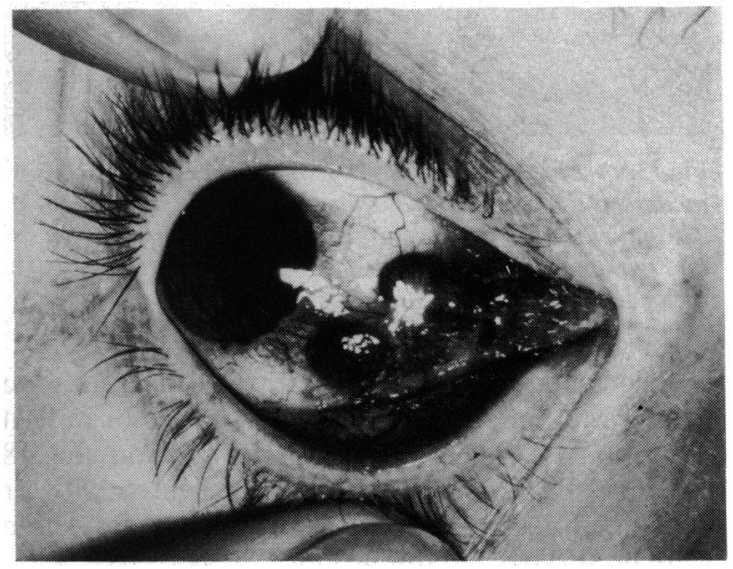

Fig. 2A Before treatment. Man of 33 years with cancerous melanosis recurrent after previous local excision and radiotherapy given elsewhere, treated by radon seed implant with a dose of 2200 rads in 72 hours. Patient was well for 26 years when a cataract developed for which patient refused treatment.

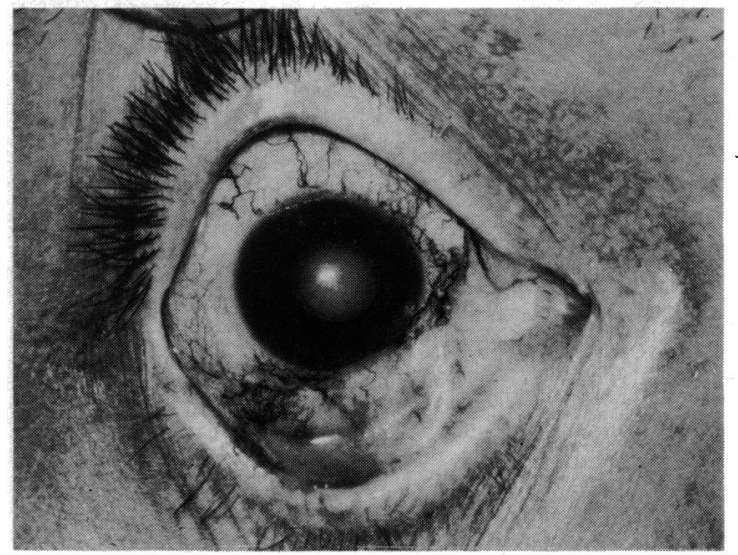

Fig. 2B Eight years after treatment. 


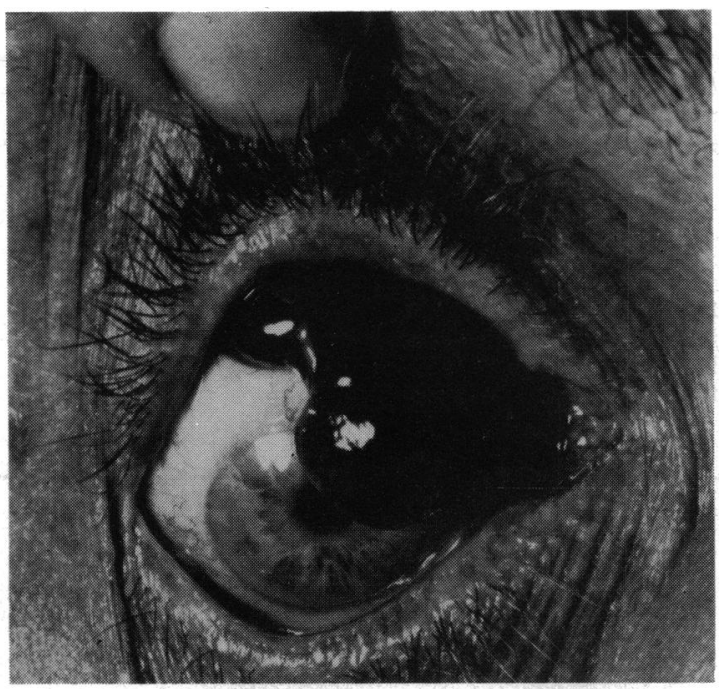

Fig. 3A Before treatment. Man of 56 years with cancerous melanosis treated with $\mathrm{x}$-ray therapy, 5000 rads in 22 days. The patient developed a cataract two years after treatment and remained well for 17 years but then died of distant metastasis. There was nolocal recurrence.

Elective dissection or irradiation of the node-free neck was not practised. However, limited or radical dissection of the neck was performed on the 18 patients (Tables $5 a$ and $b$ ) who presented with or developed cervical lymph node metastases. There were no survivors in this group.

Chemotherapy became available only during part of the period covered by this report and was employed without effect in eight cases.

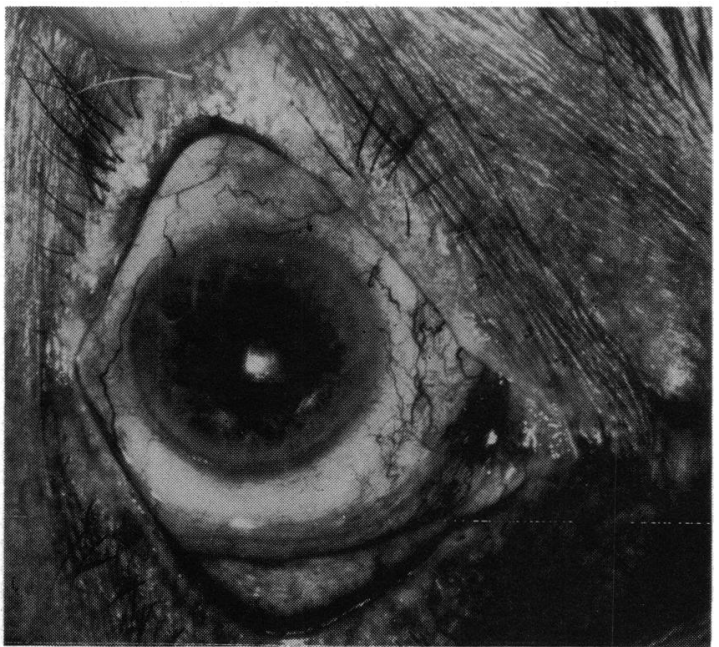

Fig. 3B 21/2 years after treatment.

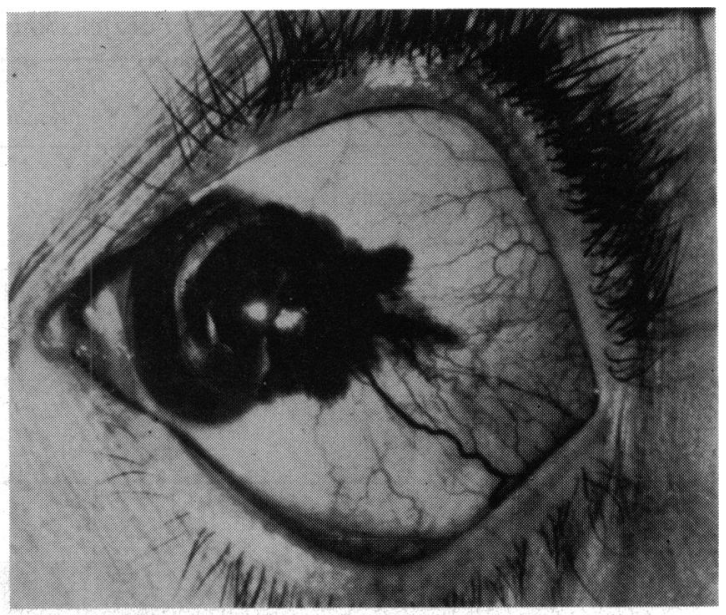

Fig. 4A Before treatment. Man of 39 years with cancerous melanoma treated by local excision and radioactive Tantalum wire applicator. Dose 5450 rads in 22 days.

It can be seen from Tables $8 \mathrm{a}, \mathrm{b}$ and $\mathrm{c}$ that of 50 cases primarily treated by radiotherapy $28(56 \%)$ survived from one to 25 years, but 13 of the surviving patients lost the eye, several from radiation damage. With the five-year period of survival as the basis, 26 out of 35 patients $(72 \cdot 2 \%)$ have survived for a period of from five to 25 years, and of those survivors 14 (54\%) have lost the eye. It would therefore seem that in nearly half the cases treated by radiotherapy it was possible both to control the disease and to save the eye.

The nine surgically treated cases are of interest as limited surgery was practised in most cases prior to referral without apparently worsening the prognosis.

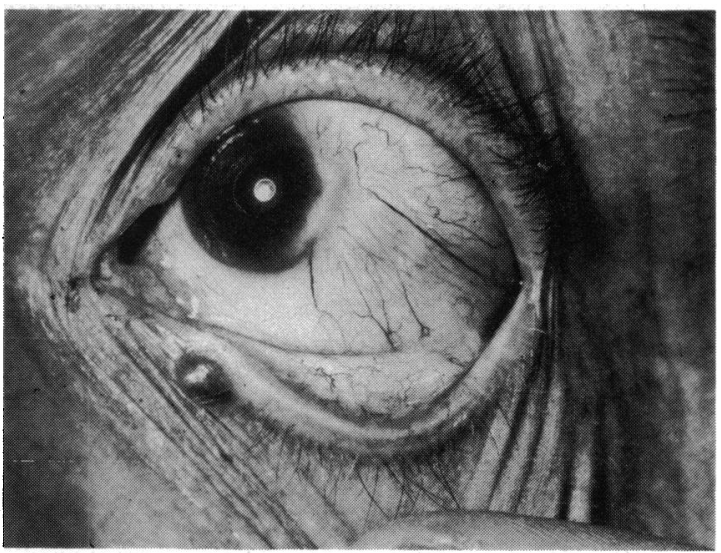

Fig. 4B 16 years after treatment. An unrelated rodent ulcer of the lower lid is present. 


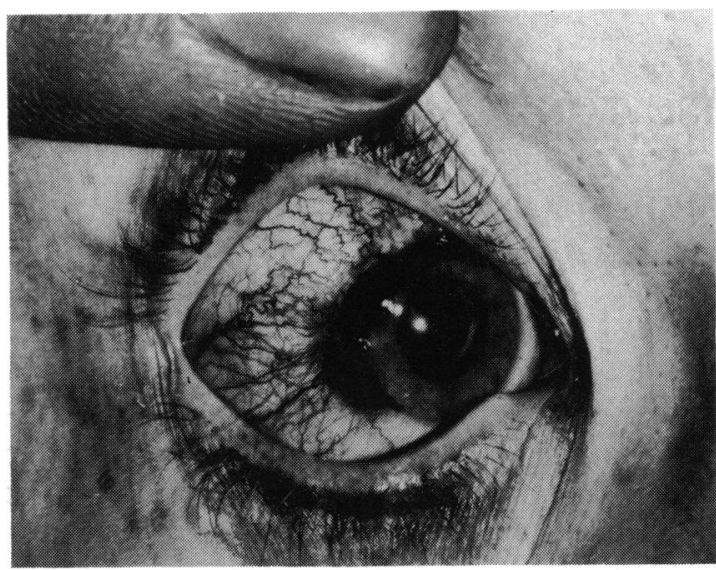

Fig. 5A Before treatment. Man of 42 years with cancerous melanosis treated by Beta rays 10000 rads in 12 fractions in 37 days.

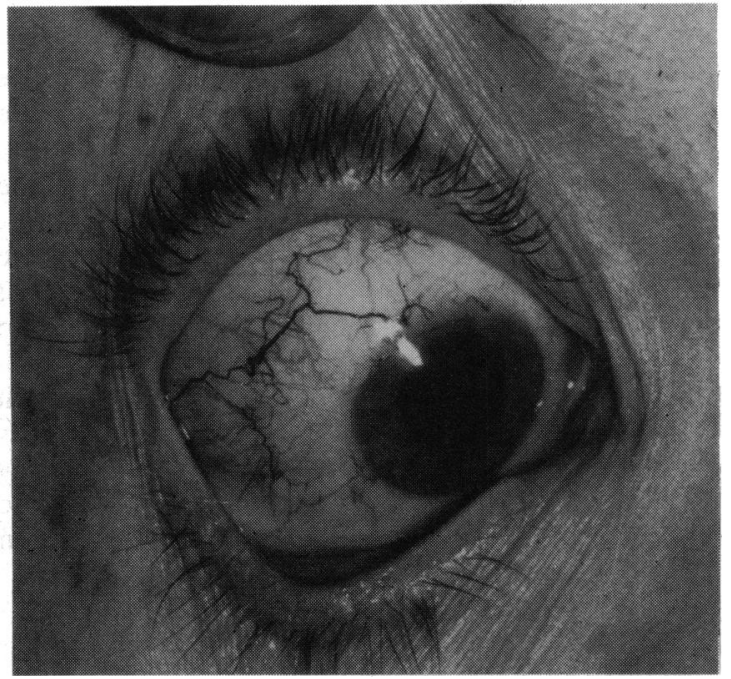

Fig. 5B Eight years after treatment. The patient was free of disease 20 years later.
The results obtained in the group of patients suffering from precancerous melanosis undergoing malignant change are strikingly good (Table 9) (Figs. 1-5). It is to be hoped that this can be attributed to the safety and wisdom of the observation policy adopted and also reflects the difference in natural history and prognosis of these lesions when compared with cancerous melanosis presenting without a precancerous phase.

We wish to acknowledge the help and support given by many of the staff of the Moorfields and Royal Eye Hospitals who referred their patients for treatment. We are particularly indebted to the late $\mathrm{Mr}$ C. D. Shapland, the late Mr F. Ridley, and the late Mr J. M. Mallett. Our thanks are also due to Professor Gowing and especially to Dr A. L. Levene of the Royal Marsden Hospital for reviewing and reporting on the pathology material, as without their considerable assistance many of the observations made in this report would not have been possible.

We wish to thank Miss Pegus of the Medical Art Department of the Royal Marsden Hospital, who kindly drew up the tables, and Mrs Chatfield for her secretarial assistance.

\section{References}

1 Jakobiec FA. Conjunctival melanoma. Unfinished business. Arch Ophthalmol 1980; 98: 1378-84.

2 Reese AB. Tumours of the eye. Hagestown: Harper and Row, 1976: 373-8.

3 Reese AB. Pre-cancerous and cancerous melanosis. Am J Ophthalmol 1966; 61: 1272-7.

4 Bernardino V, Naidoff M, Clark W, Malignant melanoma of the conjunctiva. Am J Opthalmol 1976; 82: 383-94.

5 Jay B. Naevi and melanomata of the conjunctiva. BrJ Opthalmol 1965; 49: 169-204.

6 Lederman M. Radiotherapy of epibulbar malignant melanomata. Trans Ophthalmol Soc UK 1953; 73: 399-413.

7 Lederman M. Contribution to discussion of surface melanomata of the eye and their treatment. Trans Ophthalmol Soc UK 1964; 84: 357-67.

8 Lederman M. Radiotherapy of malignant melanomata of the eye. Br J Radiol 1961; 34: 21-42.

9 Zimmerman LE. In: Jacobiec FA, ed. Ocular adnexal tumours. Birmingham, Alabama: Aesculapius, 1978.

10 Reese AB. Pre-cancerous melanosis and diffuse melanoma of the eye. Arch Ophthalmol 1938; 19: 354-65.

11 Reese AB. Pigmented tumours. Am J Ophthalmol 1947; 30: 537-65. 